\title{
PENGEMBANGAN CAKALANG (Katsuwonus pelamis) ASAR DALAM BENTUK "STEAK" DENGAN ASAP CAIR
}

\author{
Boetje Rumahrupute", Zuheid Noor") dan Suparmo"
}

\begin{abstract}
ABSTRAK
Penelitian ini bertujuan untuk mengetahui pengaruh cara perlakuan asap cair dalam larutan kuring terhadap umur simpan cakalang asar dalam bentuk "steak", secara perendaman dan penyuntikan dengan asap cair $40 \%$ dalam larutan kuring 10,5\%, selama 10 menit. Untuk semua perlakuan, "steak" dipanaskan dalam oven, didinginkan pada suhu kamar, diberi wadah styrofoam, dikemas dengan plastik "saran" dan disimpan pada suhu kamar. "Steak" cakalang segar mempunyai kadar air 70,2\%; TVB 19,6 mgN\%; pH 6,5; dan pola gel elektroforesis protein enam pita. Hasil penelitian menunjukkan bahwa perlakuan perendaman dengan asap cair $40 \%$ dalam larutan kuring dapat memperpanjang umur simpan sampai sembilan hari, sedangkan dengan perlakuan penyuntikan hanya enam hari. Perlakuan penyuntikan dan perendaman dengan larutan kuring hanya mempunyai daya simpan tiga hari. Perlakuan perendaman dan penyuntikan dengan asap cair dalam larutan kuring maupun dengan larutan kuring masing-masing mempunyai kadar air $38,2 \%: 54,1 \% ; 69,7 \% ; 65,3 \%$; TVB $19,8 \mathrm{mgN} \% ; 35,2 \mathrm{mgN} \% ; 42,8 \mathrm{mgN} \% ; 49,0 \mathrm{mgN} \%$; pH 5,$9 ; 7,1$; $7.7 ; 7,5$; fenol $0,4 \%: 0,2 \% ; 0,1 \% ; 0,1 \%$; pola elektroforesis gel protein 6 pita, 4 pita, 4 pita, 4 pita, dan kapang $9,8 \times 10^{2} ; 1,2 \times 10^{5}: 1,5 \times 10^{7} ; 1,2 \times 10^{8}$
\end{abstract}

\begin{abstract}
Development of smoked-grilled skipjack (Katsuwonus pelamis) in "steak" style using liquid smoke. By: Boetje Rumahrupute, Zuheid Noor, and Suparmo.
\end{abstract}

The purpose of this experiment was to know the effect of liquid smoke treatment in curing solution on the storage life of traditional smoked-grilled skipjack in the "steak" form. The given treatments included soaking in 40\% liquid smoke in 10.5\% curing solution for 10 minutes and injection. The "steak" was cooked in oven, cooled to room temperature, packed with styrofoam, wrapped with the "saran" and finally stored at room temperature. The initial freshness of skipjack steak was indicated by $70.20 \%$ moisture, $19.57 \mathrm{mgN} \%$ of TVB, pH 6.5 and protein electrophoresis gel pattern of six bands. The results showed that soaking in liquid smoke dissolved in curing solution was able to extent the storage life of the product up to nine days, injection with liquid smoke and "curing" solution up to six days, while the injection and soaking with curing solution up to three days. Treatment of soaking in liquid smoke dissolved in curing solution and with curing solution produced the products with $38.2 \%, 54.1 \%, 69.7 \%$ and $65.3 \%$ moisture contents: $19.8 \mathrm{mgN} \% .35 .2$ $\mathrm{mgN} \%, 42.8 \mathrm{mgN} \%$ and $49.0 \mathrm{mgN} \%$ TVB content; $\mathrm{pH}$ of $5.9,7.1,7.7$, and $7.5 ; 0.4 \%, 0.2 \%, 0.1 \%$. and $0.05 \%$ phenol contents; $6,4,4$, and 4 bands of protein electrophoresis gel pattern, $9.8 \times 10^{2}$, $1.2 \times 10^{5} .1 .5 \times 10^{7}$ and $1.2 \times 10^{8}$ mould number respectivelly.

KEYWORDS: smoke grilled skipjack, liquid smoke.

\section{PENDAHULUAN}

Proses pengasaran ikan yang dilakukan di Maluku selama ini mempunyai kelemahan antara lain: dilakukan di tempat terbuka, membutuhkan waktu pengasaran kurang lebih delapan jam, pemakaian bahan bakar (kayu atau tempurung kelapa) cukup banyak, prosesnya sulit dikendalikan serta kurangnya perhatian terhadap sanitasi dan higina. Menurut Gorbatov et al. (1971) dan Maga (1987), beberapa kelemahan pengasapan tradisional antara lain: cita rasa dan konsentrasi konstituen asap tidak seragam. waktu dan suhu yang tidak sama, sehingga produk yang dihasilkan tidak seragam serta kemungkinan terbentuknya senyawa hidrokarbon aromatik polisiklik (benzo( $\alpha$ ) piren) yang bersifat karsinogenik

Dalam upaya perbaikan pengolahan cakalang asar telah dilakukan beberapa penelitian antara lain dengan perekayasaan alat pengasar (Setiabudi et al., 1982; Syarief et al., 1983). Ditinjau dari segi pemasaran maupun pengolahannya, terlihat bahwa cakalang asar merupakan produk olahan yang utama bagi masyarakat Maluku. Dengan intensifnya kegiatan produksi maupun konsumsi produk tersebut diperlukan suatu teknologi yang dapat menghasilkan ikan cakalang asar dengan sifat sensoris yang menarik sehingga dapat dipasarkan di luar daerah Maluku. Salah satu upaya peningkatan mutu dan

Peneliti pada Balai Pengkajian Teknologi Pertanian Ambon

Dosen Fakultas Pascasarjana, Universitas Gadjah Mada, Yogyakarta 
perpanjangan umur simpan cakalang asar adalah dengan menggunakan asap cair

Eklund et al. (1982) mengemukakan bahwa asap cair lebih mudah diaplikasikan karena konsentrasinya dapat dikontrol sehingga memberikan cita rasa dan warna yang seragam. Selanjutnya dikatakan bahwa asap cair telah disetujui oleh banyak negara untuk digunakan pada pangan dan sekarang ini banyak digunakan dalam produk-produk daging lunak. Selain itu asap cair tidak menunjukkan karsinogenik atau sifat-sifat toksik. Hal ini memperkuat pernyataan Hollenbeck (1978) yang menyatakan bahwa asap cair mempunyai sifat antibakterial, lebih mudah diaplikasikan dan lebih aman dari asap konvensional, serta merupakan fraksi tar yang mengandung hidrokarbon polisiklik aromatik yang telah dipisahkan, sehingga produk asap cair bebas polutan dan karsinogen. Menurut Yulistiani (1997), asap cair yang berasal dari hasil pirolisis tempurung kelapa mempunyai kemampuan penghambatan terhadap pertumbuhan bakteri patogen

Penggunaan asap cair sebagai ganti pengasaran cakalang asar mempunyai peluang untuk dikembangkan di Maluku, karena mudah diaplikasikan serta melindungi konsumen dari bahan karsinogenik yang biasanya terbentuk pada metode pengasapan tradisional serta mempunyai ketersediaan bahan baku yang melimpah. Tujuan dari penelitian ini adalah untuk mengetahui pengaruh cara aplikasi asap cair sebagai ganti pengasaran terhadap umur simpan cakalang asar dalam bentuk "steak"

\section{BAHAN DAN METODE}

\section{Bahan}

Bahan utama yang digunakan dalam penelitian ini adalah ikan cakalang (Katsuwonus pelamis) sebanyak 90 ekor yang masih segar dengan bobot rata-rata $3 \mathrm{~kg} / \mathrm{ekor}$. Ikan tersebut merupakan hasil tangkapan nelayan di Kabupaten Cilacap, Jawa Tengah pada bulan Oktober 1997 dengan nilai TVB $20,2 \mathrm{mgN} \%$ penelitian untuk penentuan konsentrasi asap cair dan bulan November 1997 dengan nilai TVB 19,6 mgN\% untuk aplikasi asap cair. Ikan cakalang yang baru didaratkan dipilih yang masih segar, dicuci dan disusun dan dilapisi dengan hancuran es, selanjutnya dibawa ke Laboratorium Fakultas Teknologi Pertanian, Universitas Gadjah Mada Yogyakarta untuk diolah dan dianalisis.

Bahan tambahan yang digunakan adalah asap cair yang berasal dari hasil pirolisis tempurung kelapa pada suhu $400^{\circ} \mathrm{C}$, diperoleh dari Fakultas Teknologi Pertanian, Universitas Gadjah Mada Yogyakarta. Sebagai bahan pengemas digunakan plastik "saran" dengan wadah sterofoam, sedangkan pemanas- annya menggunakan oven listrik (yang tidak berasap)

\section{Metode Penelitian}

\section{Penentuan konsentrasi asap cair}

Konsentrasi asap cair ditentukan berdasarkan kurva standar fenol yang ditera dengan spektrofotometer pada panjang gelombang $750 \mathrm{~nm}$. Ikan dicuci, isi perutnya dibuang kemudian dipotong berbentuk "steak" dan direndam selama 5, 10 dan 15 menit dalam asap cair dengan konsentrasi 40\%, $20 \%$, dan $13 \%$ yang telah ditambahkan larutan kuring $(\mathrm{NaCl} 10 \%$ dan fosfat $0,5 \%$ )

Suhu pemanasan untuk satu jam pertama adalah $40^{\circ}-50^{\circ} \mathrm{C}$, enam jam berikutnya berkisar antara $80^{\circ} \mathrm{C}$. diteruskan dengan $40^{\circ}-50^{\circ} \mathrm{C}$ pada satu jam terakhir. Setelah selesai proses pemanasan, stik dibiarkan pada suhu kamar hingga dingin, kemudian ditempatkan pada wadah styrofoam dan dikemas dalam plastik "saran". Produk tersebut selanjutnya disimpan pada suhu kamar $\left(26^{\circ}-28^{\circ} \mathrm{C}\right)$ dan diamati secara visual sampai tumbuhnya kapang untuk menentukan batas akhir penyimpanan. Cara ini adalah untuk mengetahui konsentrasi asap cair, waktu perendaman yang optimum dan waktu penolakan terhadap stik cakalang asar yang disukai secara sensoris yang akan digunakan pada penelitian aplikasi asap cair, untuk mengetahui perbedaan produk dari masing-masing perlakuan

\section{Aplikasi asap cair}

Ikan cakalang yang telah dipotong melintang berbentuk stik dicuci kemudian dibagi menjadi empat bagian. Satu bagian disuntik $\left(A_{0}\right)$ dan bagian lainnya direndam $\left(A_{1}\right)$ masing-masing dengan larutan kuring $\left(B_{0}\right)$ dan asap cair $40 \%$ yang ditambahkan larutan kuring $10,5 \%\left(B_{0}\right)$. Setelah selesai penyuntikan dan perendaman, stik tersebut ditiriskan selama 20 menit. Stik diatur di atas rak-rak supaya merata di dalam oven dan dipanaskan pada suhu seperti yang dilakukan untuk penentuan konsentrasi asap cair dan dianalisis selama sembilan hari penyimpanan ( $26^{\circ}$. $28^{\circ} \mathrm{C}$ ) dengan interval pengujian tiga hari.

\section{Uji/analisis yang dilakukan terdiri atas:}

a. Kimiawi

- Kadar air (Hasegawa, 1987)

- Total Volatile Bases (TVB) (Hasegawa, 1987)

- pH (Hasegawa, 1987)

- Kandungan fenol dengan metode Sunter et al. (1989) dalam Wahyuningtyas (1997) 
- Perubahan protein (Elektroforesis) dengan metode Laemli (1970)

- Total kapang dengan metode Pitt \& Hocking (1985)

b. Organoleptik

Pengamatan dilakukan terhadap parameter subjektif (warna, bau, rasa, dan tekstur) dengan skor tiga untuk warna, skor lima untuk bau dan rasa, serta skor tujuh untuk tekstur seperti terlihat pada lembar pengamatan (Lampiran 1). Nilai yang disajikan merupakan rata-rata dari hasil analisis oleh 15 panelis yang diseleksi dari 21 panelis. Analisis statistik dilakukan dengan menggunakan rancangan acak lengkap pola faktorial dengan dua kali ulangan. Data dianalisis dengan sidik ragam (Anova) dan dilanjutkan dengan uji beda nyata jujur (BNJ)/Honestly Significant Difference $=(H S D)$ menurut Steel \& Torrie (1981).

\section{HASIL DAN BAHASAN}

Dari hasil analisis statistik terhadap penggunaan konsentrasi asap cair 13\%, 20\%, dan $40 \%$ dengan lama perendaman 5 menit, 10 menit, dan 15 menit dalam larutan kuring $10,5 \%$, diperoleh bahwa asap cair $40 \%$ dengan lama perendaman 10 menit menghasilkan stik cakalang asar yang disukai panelis karena memberikan warna coklat, agak berbau asap, dan tekstur agak keras (Tabel 1) dengan umur simpan lebih dari enam hari.

Analisis lanjut dengan uji beda nyata jujur (BNJ), menunjukkan bahwa konsentrasi asap cair $40 \%$ dengan lama perendaman 10 menit memberikan perbedaan yang nyata terhadap warna, bau, dan rasa stik cakalang asar (sesuai uji kesukaan), sedangkan tekstur tidak berbeda nyata.
Gambar 1, 2, 3, dan 4 dengan skala pembedaan 1-3 untuk warna, 1-5 untuk bau dan rasa serta 1-7 untuk tekstur mempunyai nilai rata-rata warna, bau rasa, dan tekstur pada penyimpanan hari ke sembilan masing-masing adalah 2,$0 ; 3,5 ; 3.1$; dan 4,8 . Kenyataan ini menunjukkan bahwa senyawa-senyawa kimia dalam asap cair dapat memberikan kontribusi terhadap pembentukan warna, bau, rasa, dan tekstur Menurut Girard (1992), fenol dalam produk asapan berperan dalam pembentukan cita rasa, sedangkan karbonil membentuk warna dan cita rasa. Selanjutnya dikatakan bahwa senyawa-senyawa fenolat tertentu seperti guaiakol, 4-metil guaiakol, 2,6-dimetoksi feno dan seringol menentukan cita rasa dari bahan pangan yang diasap, di mana guaiakol akan memberikan rasa asap dan seringol memberikan aroma asap. Menurut Daun (1979); Ruiter (1979); dan Girard (1992) senyawa karbonil yang banyak berperan dalam reaksi pembentukan warna adalah formaldehid dan acetol.

Produk dengan perlakuan penyuntikan dengan menggunakan asap cair dalam larutan kuring dan perendaman dalam larutan kuring mengalami penurunan mutu dengan laju yang paling cepat sehingga pengamatan organoleptik terhadap produk terpaksa diakhiri pada hari ke tiga untuk cara aplikasi penyuntikan dengan menggunakan asap cair dalam larutan kuring dan hari ke enam untuk cara aplikasi perendaman dalam larutan kuring karena sudah ditumbuhi kapang, sedangkan parameter kimiawi dianalisis sampai akhir penyimpanan

Hasil analisis kimiawi ikan cakalang segar dan olahannya dalam bentuk Stik dapat dilihat pada Tabel 2. Dari hasil analisis statistik diketahui bahwa cara

Tabel 1. Analisis statistik parameter organoleptik dari stik ikan cakalang dengan konsentrasi asap cair dan lama perendaman.

Table 1. Statistical analysis of sensory properties of skipjack steak with different liquid smoke concentration and soaking times.

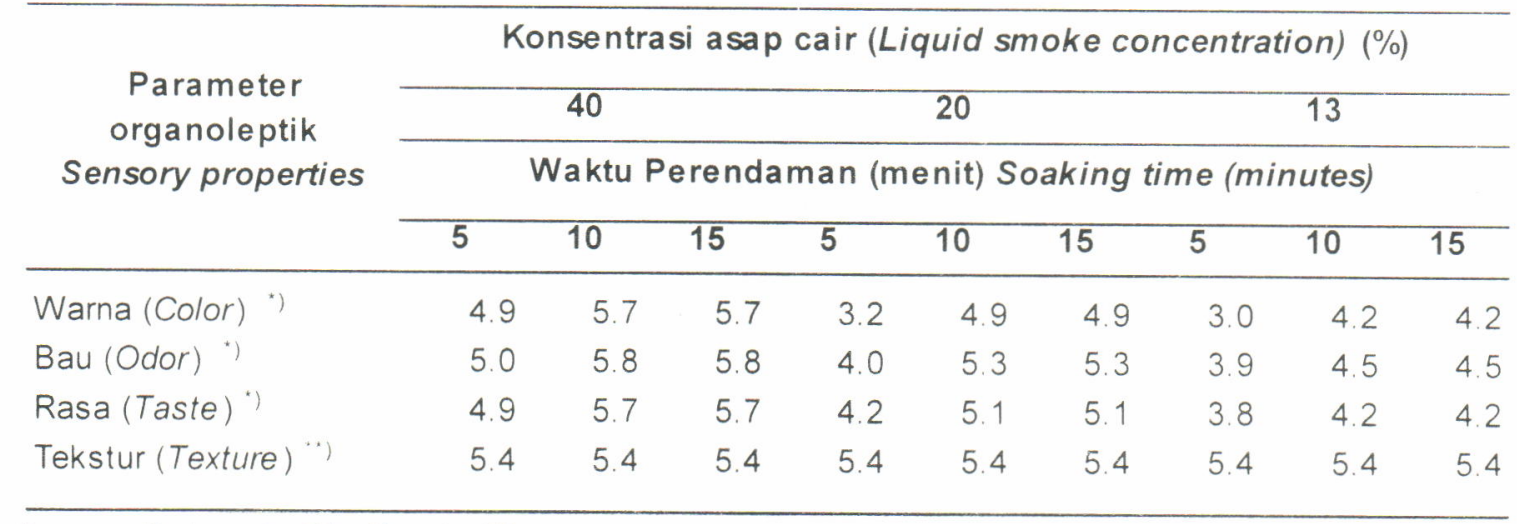

\footnotetext{
*) Beda nyata (Significantly different)

${ }^{* *}$ Tidak beda nyata (Insignificantly different)
} 


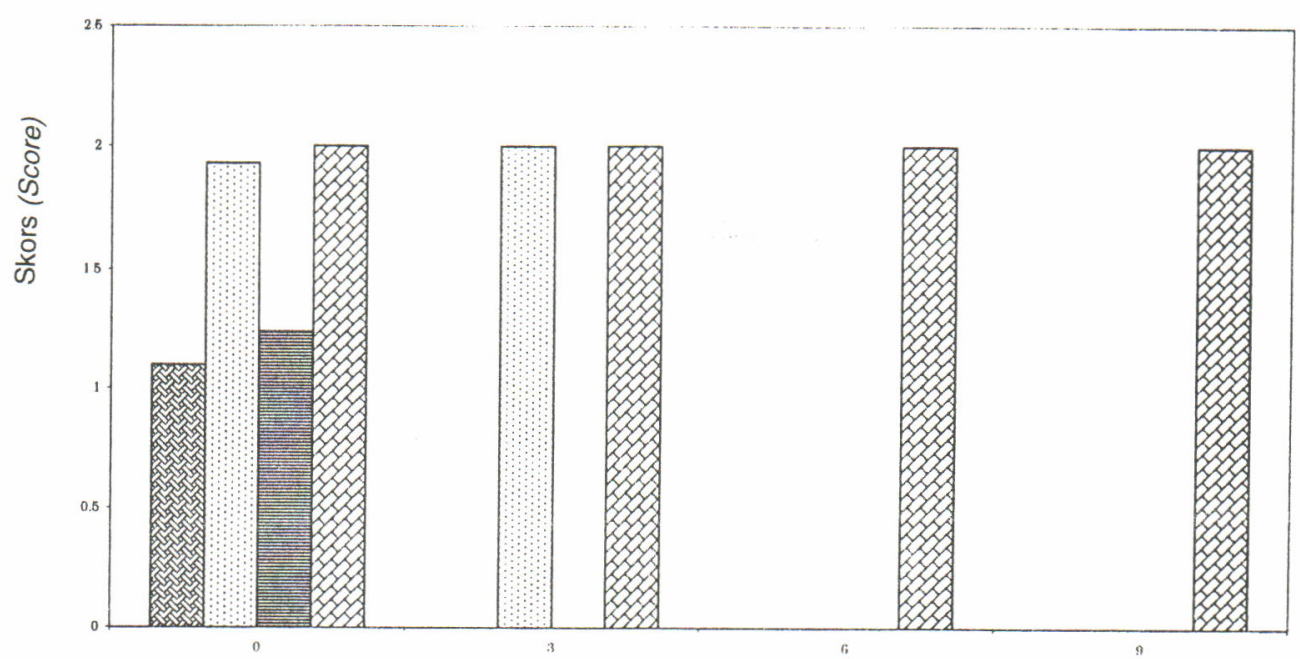

Waktu perendaman (hari) Storage time (day)

口 Injeksi dengan larutan kuring (Injection of curing)

๑ Injeksi dengan asap cair dalam larutan kuring (Injection of liquid smoke dissolved in curing solution)

目 Perendaman dengan larutan kuring (Soaking in curing solution)

๑ Perendaman dengan asap cair dalam larutan kuring (Soaking in liquid smoke dissolved in curing solution)

Gambar 1. Perubahan mutu sensoris terhadap warna stik cakalang asar selama penyimpanan pada suhu kamar

Figure 1. Color quality changes (organoleptically) of smoked grilled skipjack steak during room temperature storage.

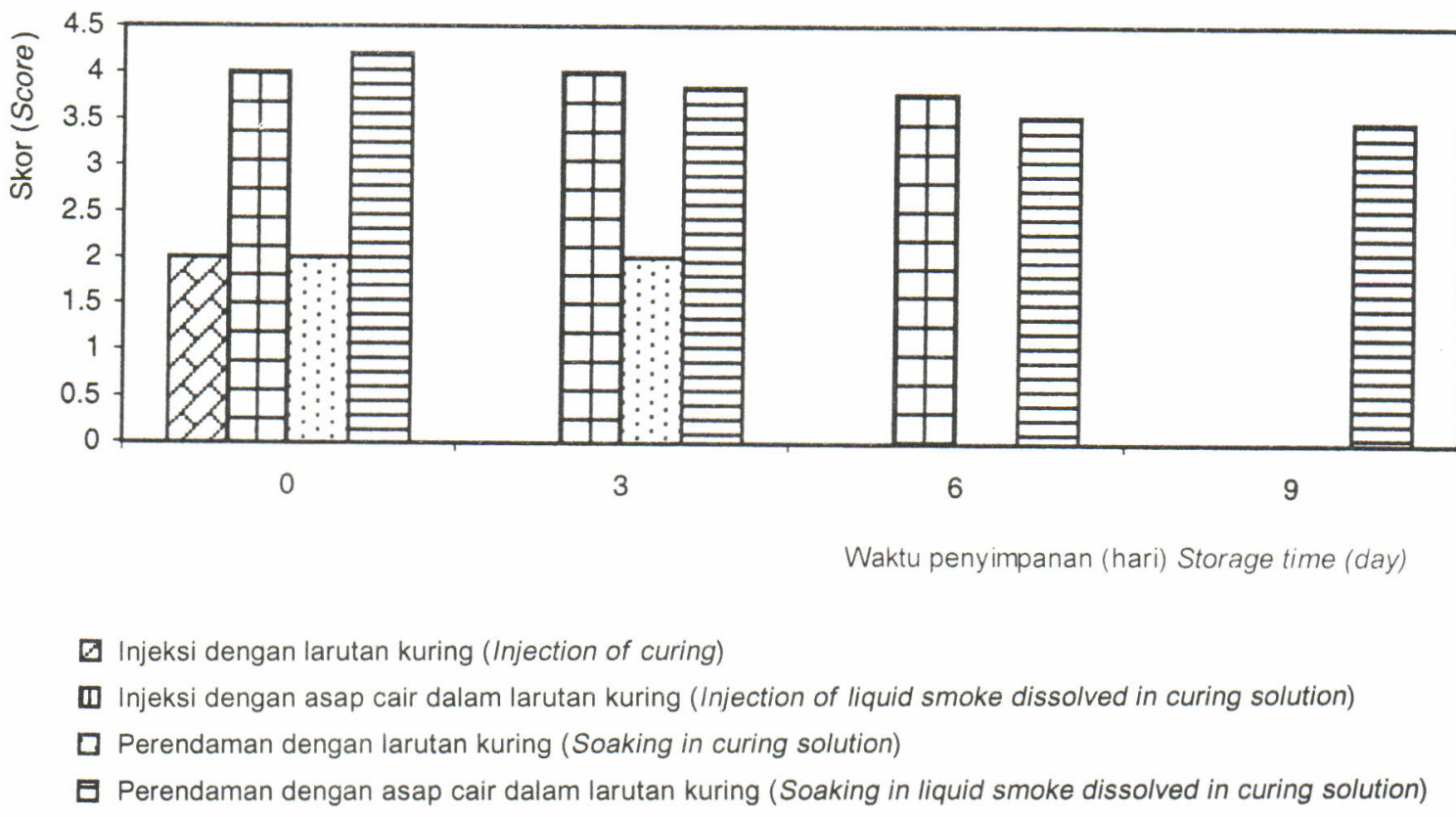

Gambar 2. Perubahan mutu sensoris terhadap bau stik cakalang asar selama penyimpanan pada suhu kamar.

Figure 2. Odor quality changes (organoleptically) of smoked grilled skipjack steak during room temperature storage. 


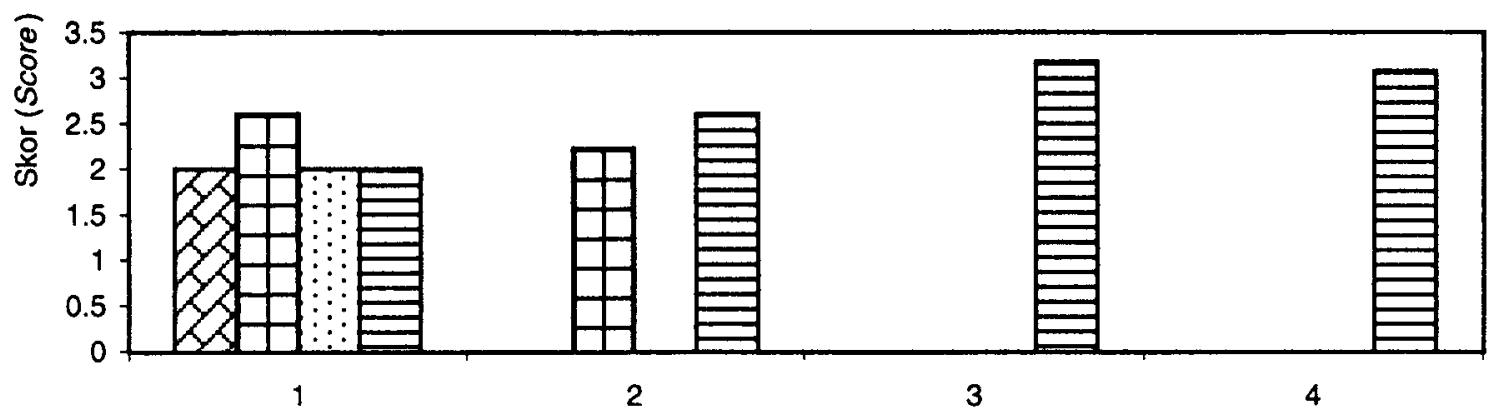

Waktu penyimpanan (hari) Storage time (day)

U Injeksi dengan larutan kuring (Injection of curing)

$\mathbf{m}$ Injeksi dengan asap cair dalam larutan kuring (Injection of liquid smoke dissolved in curing solution)

$\square$ Perendaman dengan larutan kuring (Soaking in curing solution)

Q Perendaman dengan asap cair dalam larutan kuring (Soaking in liquid smoke dissolved in curing solution)

Gambar 3. Perubahan mutu sensoris terhadap rasa stik cakalang asar selama penyimpanan pada suhu kamar.

Figure 3. Taste quality changes (organoleptically) of smoked grilled skipjack steak during room temperature storage.

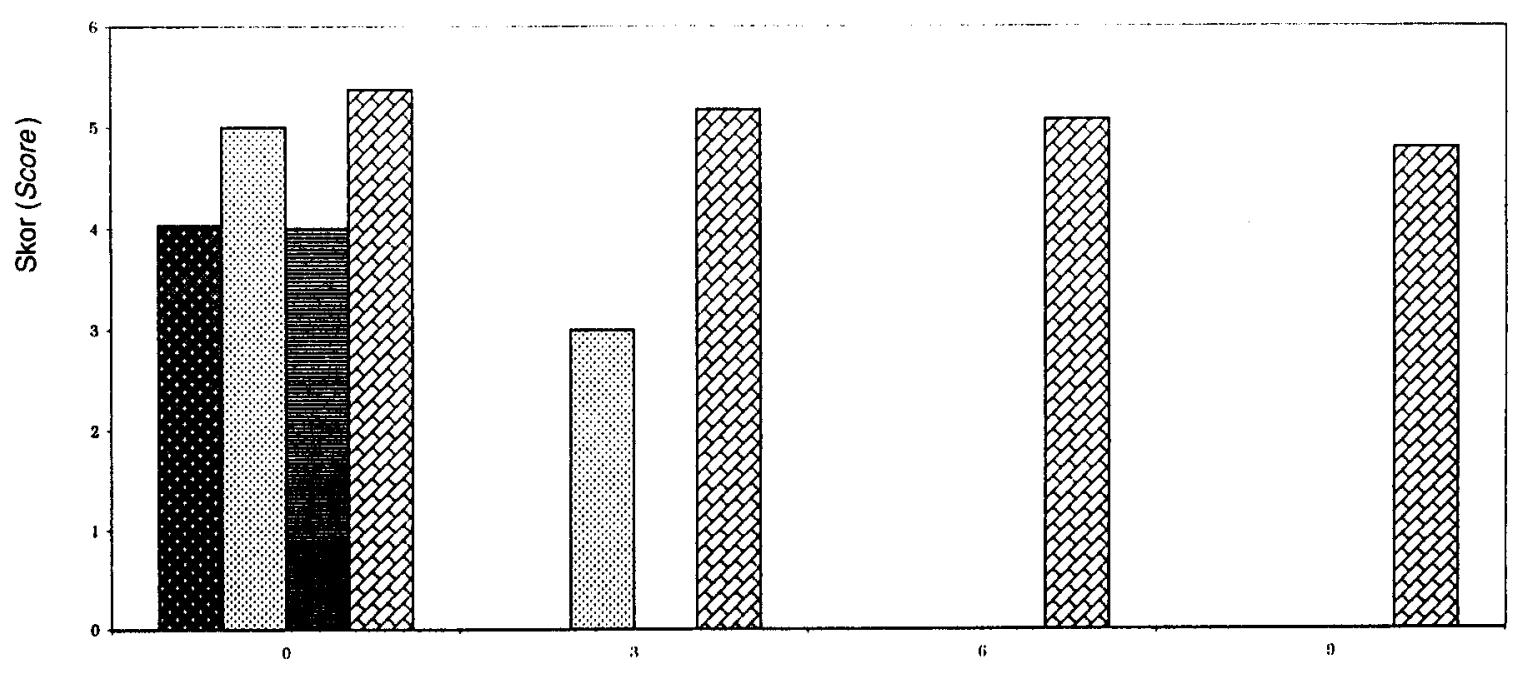

Waktu penyimpanan (dari) Storage time (day)

Injeksi dengan larutan kuring (Injection of curing)

W Injeksi dengan asap cair dalam larutan kuring (Injection of liquid smoke dissolved in curing solution)

Perendaman dengan larutan kuring (Soaking in curing solution)

- Perendaman dengan asap cair dalam larutan kuring (Soaking in liquid smoke dissolved in curing solution)

Gambar 4. Perubahan mutu sensoris terhadap tekstur stik cakalang asar selama penyimpanan pada suhu kamar.

Figure 4. Texture quality changes (organoleptically) of smoked grilled skipjack steak during room temperature storage. 
Tabel 2. Spesifikasi bahan mentah dan hasil olahan stik ikan cakalang

Table 2. Raw material and final product specification of smoked grilled skipjack steak.

\begin{tabular}{|c|c|c|c|c|c|}
\hline \multirow{3}{*}{$\begin{array}{l}\text { Komposisi } \\
\text { Composition }\end{array}$} & \multirow{3}{*}{$\begin{array}{c}\text { Ikan } \\
\text { segar } \\
\text { Fresh } \\
\text { fish }\end{array}$} & \multicolumn{4}{|c|}{$\begin{array}{l}\text { Pengolahan cakalang steak asar } \\
\text { Processing of skipjack smoke steak }\end{array}$} \\
\hline & & \multicolumn{2}{|c|}{ Injeksi (Injection) } & \multicolumn{2}{|c|}{ Perendaman (Soaking) } \\
\hline & & $\begin{array}{l}\text { Larutan } \\
\text { perendaman } \\
\text { Curing } \\
\text { solution }\end{array}$ & $\begin{array}{c}\text { Asap cair } \\
\text { Liquid smoke }\end{array}$ & $\begin{array}{l}\text { Larutan } \\
\text { perendaman } \\
\text { Curing } \\
\text { solution }\end{array}$ & $\begin{array}{l}\text { Asap cair } \\
\text { Liquid smoke }\end{array}$ \\
\hline $\begin{array}{l}\text { Kadar Air }(\%) / \\
\text { Moisture content (\%) }\end{array}$ & 70.3 & 65.3 & 54.1 & 69.7 & 38.1 \\
\hline TVB (mg N \%) & 19.6 & 49.0 & 35.2 & 42.8 & 19.8 \\
\hline $\mathrm{pH}$ & 6.5 & 7.5 & 7.1 & 7.7 & 5.9 \\
\hline Fenol (Phenol) (\%) & 0.4 & 0.1 & 0.2 & 0.1 & 0.4 \\
\hline $\begin{array}{l}\text { Jumlah kapang (log) } \\
\text { Mould number (log) }\end{array}$ & * & 0.1 & 5.1 & 7.2 & 3.0 \\
\hline $\begin{array}{l}\text { Protein (pita) } \\
\text { Protein (band) }\end{array}$ & 6 & 4 & 4 & 4 & 6 \\
\hline
\end{tabular}

Tidak dianalisis (not analyzed)

aplikasi penyuntikan, perendaman, waktu penyimpanan, dan kombinasi cara aplikasi, secara keseluruhan berpengaruh nyata $(P>0,05)$ terhadap karakteristik kimia dan mikrobiologis stik cakalang asar (Tabel 3). Dari analisis lanjut dengan uji HSD, diketahui bahwa cara aplikasi perendaman dengan asap cair dalam larutan kuring memberikan perbedaan karakteristik kimia dan mikrobiologis yang nyata pada stik cakalang asar sampai akhir penelitian (hari ke-9).

Pada akhir penyimpanan, produk mempunyai kadar air 38,1\%; TVB 29,8 mgN\%, pH 5,9; fenol 0,4\%; dan total kapang $9,3 \times 10^{2}$ dengan sifat sensoris warna coklat, berbau asap, serta mempunyai tekstur agak keras.

Selama penyimpanan pada suhu kamar, produk yang diolah melalui perendaman dengan asap cair dalam larutan kuring lebih efektif untuk menghambat laju peningkatan kadar air, TVB, pH, dan total kapang, juga dapat memperkecil kehilangan fenol, serta dapat mempertahankan subunit protein, dibanding dengan cara aplikasi lain. Baik peningkatan kadar air, TVB, $\mathrm{pH}$, total kapang maupun penurunan fenol dan subunit protein selama penyimpanan berbeda sesuai cara aplikasi. Hal ini diduga bahwa penyerapan senyawa-senyawa kimia dalam asap cair dari permukaan stik cakalang selama 10 menit merata penyebarannya ke dalam daging ikan sehingga dapat menghambat pertumbuhan mikroba dibandingkan dengan penyebarannya dari dalam daging ke permukaan seperti yang dilakukan dengan cara pe- nyuntikan. Menurut Eklund et al. (1982), asap cair yang dikombinasikan dengan $\mathrm{NaCl}$ efektif menghambat pertumbuhan dan produksi toksin oleh Clostridium botulinum tipe $A$ dan $B$ pada proses pengasapan panas "white fish", "chub" dan "carp" yang disimpan pada suhu $25^{\circ} \mathrm{C}$ selama $7-14$ hari.

Pola peningkatan kadar air yang terlalu cepat tidak diinginkan pada produk ini, karena kadar air yang tinggi dapat dimanfaatkan sebagai media tumbuh oleh bakteri dan kapang untuk berkembang. Menurut Witigna (1973), faktor yang sangat besar pengaruhnya terhadap daya tahan suatu produk pangan hasil olahan adalah kadar air. Makin tinggi kadar air. semakin cepat mikroba berkembang dengan baik sehingga menyebabkan proses kemunduran mutu akan berlangsung dengan cepat. Sebaliknya makin rendah kadar air makin lambat pertumbuhan mikroba Peningkatan kandungan TVB diduga akibat basabasa menguap yang dihasilkan dari penguraian protein oleh aktivitas mikroba yang mengarah pada proses pembusukan. Menurut James (1978), proses penguraian protein dan derivatnya oleh mikroba selama penyimpanan akan menghasilkan basa-basa menguap seperti amonia, trimethylamina dan hidrogen sulfida. Perubahan $\mathrm{pH}$ ditentukan oleh kondisi lingkungan. Ray \& Daescel (1993) berpendapat bahwa $\mathrm{pH}$ lingkungan yang rendah dapat menyebabkan denaturasi enzim dan ketidakstabilan bakteri sehingga menghambat pertumbuhan dan menurunkan daya hidup sel bakteri. Menurut Pearson \& Tauber (1984), asap dapat mengawetkan karena adanya aksi 
Tabel 3. Komposisi kimia cakalang asar selama penyimpanan suhu kamar.

Table 3. Chemical composition of skipjack smoked grilled smoke during storage at room temperature.

\begin{tabular}{|c|c|c|c|c|c|c|c|c|}
\hline \multirow[b]{2}{*}{$\begin{array}{l}\text { Aplikasi } \\
\text { perlakuan * } \\
\text { Application of } \\
\text { treatment }\end{array}$} & \multirow[b]{2}{*}{$\begin{array}{c}\text { Aplikasi larutan * } \\
\text { Application of solution }\end{array}$} & \multirow[b]{2}{*}{$\begin{array}{c}\text { Waktu } \\
\text { penyim panan } \\
\text { (hari) } \\
\text { Storage time } \\
\text { (day) }\end{array}$} & \multicolumn{6}{|c|}{ Parameter } \\
\hline & & & $\begin{array}{c}\text { Kadar air } \\
\text { Moisture } \\
\text { content } \\
(\%)\end{array}$ & $\begin{array}{c}\text { TVB } \\
(\mathrm{mgN} \%)\end{array}$ & $\mathrm{pH}$ & $\begin{array}{c}\text { Fenol } \\
\text { Phenol } \\
(\%)\end{array}$ & $\begin{array}{l}\text { Prote in } \\
\text { (pita) } \\
\text { Protein } \\
\text { (band) }\end{array}$ & $\begin{array}{l}\text { Jumlah } \\
\text { kapang } \\
\text { Mold } \\
\text { number } \\
\text { (log) }\end{array}$ \\
\hline \multirow{9}{*}{$\begin{array}{l}\text { Penyuntikan } \\
\text { Injection }\end{array}$} & \multirow[t]{4}{*}{ Kuring (Curing) } & 0 & 46.9 & 25.2 & 6.5 & 0.6 & 6.0 & 3.8 \\
\hline & & 3 & 51.7 & 31,6 & 7.0 & 0.4 & 3.0 & 4.7 \\
\hline & & 6 & 60.0 & 46.4 & 7.1 & 0.2 & 4.0 & 6.6 \\
\hline & & 9 & 65.3 & 49.0 & 7.5 & 0.1 & 4.0 & 8.6 \\
\hline & \multirow{4}{*}{$\begin{array}{l}\text { Asap cair dalam larutan } \\
\text { kuring } \\
\text { Liquid smoke in curing } \\
\text { solution }\end{array}$} & 0 & 40.0 & 19.8 & 6.2 & 0.9 & 6.0 & 1.0 \\
\hline & & 3 & 49.1 & 21.8 & 6.3 & 0.6 & 6.0 & 3.0 \\
\hline & & 6 & 51.2 & 26.9 & 6.4 & 0.3 & 6.0 & 4.6 \\
\hline & & 9 & 54.1 & 35.2 & 7.1 & 0.2 & 4.0 & 5.1 \\
\hline & \multirow[t]{4}{*}{ Kuring (Curing) } & 0 & 49.5 & 26.4 & 5.2 & 0.7 & 4.0 & 3.0 \\
\hline \multirow{7}{*}{$\begin{array}{l}\text { Perendanan } \\
\text { Soaking }\end{array}$} & & 3 & 53.6 & 30.1 & 6.9 & 0.4 & 4.0 & 4.0 \\
\hline & & 6 & 62.5 & 38.0 & 6.9 & 0.2 & 4.0 & 5.8 \\
\hline & & 9 & 69.7 & 42.9 & 7.7 & 0.1 & 4.0 & 7.2 \\
\hline & \multirow{4}{*}{$\begin{array}{l}\text { Asap cair dalam larutan } \\
\text { kuring } \\
\text { Liquid smoke in curing } \\
\text { solution }\end{array}$} & 0 & 33.3 & 12.7 & 5.1 & 1.1 & 6.0 & 1.0 \\
\hline & & 3 & 34.6 & 13.2 & 5.4 & 0.7 & 6.0 & 1.5 \\
\hline & & 6 & 35.1 & 16.4 & 5.9 & 0.4 & 6.0 & 2.1 \\
\hline & & 9 & 38.1 & 19.8 & 5.9 & 0.4 & 6.0 & 3.0 \\
\hline
\end{tabular}

Berbeda nyata (Significantlly different) $(\mathrm{p}<0.05)$

anti bakteri dari senyawa-senyawa fenol, asam asetat, dan formaldehid yang terkandung di dalamnya. Penggunaan asap cair dalam larutan kuring pada pengolahan stiak cakalang asar selain memberikan cita rasa yang khas, pembentukan warna, dan sebagai pengawet, juga memberikan kontribusi terhadap perubahan protein melalui kondisi $\mathrm{pH}$ yang terbentuk.

Pada produk asap yang diolah dengan penyuntikan asap cair, perubahan mulai terlihat pada hari ke enam dan yang diolah dengan penyuntikan maupun perendaman dalam larutan kuring sudah terlihat pada hari ke tiga. Menurut Bechtel \& Parrish (1983), selama penyimpanan terjadi perubahan protein dan terdapat subunit protein baru yang terbentuk akibat pemecahan beberapa subunit protein baik dari protein yang larut air maupun yang tidak larut.

Dengan demikian cara aplikasi perendaman asap cair lebih efektif dalam menghambat perubahan protein selain menghasilkan cita rasa, pembentukan warna, dan sebagai pengawet juga dapat mempertahankan protein pada stik cakalang asar selama penyimpanan dibandingkan dengan cara lain. Hal ini terlihat bahwa sampai akhir penyimpanan masih terdapat enam pita protein. Pembentukan subunit protein ini, diduga merupakan hasil agregasi dua atau lebih subunit protein. Sikorski (1979) menyatakan bahwa secara umum pemanasan selama proses pengolahan pangan dapat mengakibatkan terbentuknya agregasi antara protein-protein dan nonprotein. Selanjutnya dikatakan bahwa agregasi ini terjadi akibat terbentuknya ikatan silang disulfida atau molekul yang beragregasi.

Kandungan fenol yang terdapat dalam asap cair memberikan kontribusi untuk menghambat pembentukan spora. Menurut Daun (1979), efek anti bakteri yang dihasilkan selama proses pengasapan tradisional selain ditimbulkan akibat pemanasan dan pengeringan, terutama adalah karena adanya senyawa-senyawa kimia yang terkandung dalam asap seperti fenol, formaldehid, asam asetat, dan kreosat yang menempel di bagian permukaan, yang dapat menghambat pembentukan spora dan pertumbuhan beberapa jenis bakteri dan kapang. Senyawa fenol menghambat pertumbuhan bakteri dengan cara memperpanjang fase "lag". Menurut Reynold (1993), fenol merupakan senyawa antiseptik dan desinfektan terhadap berbagai mikroba, tetapi akan lebih efektif bila terdapat dalam larutan asam organik. Jadi terdapatnya fenol bersama asam asetat di dalam asap cair sangat menguntungkan, terbukti dari hasil 
pengamatan aktivitas anti bakteri dan kapang yang ditunjukkan oleh kombinasi senyawa ini lebih besar dibandingkan dengan perlakuan iain.

\section{KESIMPULAN DAN SARAN}

1. Produk stik cakalang asar yang diolah dengan aplikasi asap cair $40 \%$ dalam larutan kuring $10,5 \%$ dengan lama perendaman 10 menit sampai akhir penyimpanan (sembilan hari) mempunyai sifat sensoris: warna coklat, bau, dan rasa asap tajam serta tekstur agak keras dengan kadar air 38,14\%, TVB 29,77 mg N\%, pH 5,41, pola protein tidak berubah (enam pita), dan kapang $9,3 \times 10^{2}$.

2. Penurunan mutu stik cakalang asar secara kimiawi dan mikrobiologi terjadi sejalan dengan pola penurunan mutu sensoris.

3. Umur simpan stik cakalang asar dengan cara aplikasi perendaman dengan asap cair dalam larutan kuring masih dapat ditingkatkan dengan cara penyemprotan

\section{DAFTAR PUSTAKA}

Bechtel, P.J. and Parrish, F.C. Jr. 1983. Effect of post mortem storage and temperature on muscle protein degradation. Analysis by SDS Gel Ellectrophoresis. J. Food Sci. 48: 294.

Daun, H. 1979. Interaction of wood smoke component and foods. Food Techol. 33 (59): 66-71.

Eklund, M.W., Pelroy; G.A., Paranjpye, R., Peterson, M.E., and Teeny, F.M. 1982. Inhibitor of Clostridium botulinum types $\mathrm{A}$ and $\mathrm{B}$ toxin production by liquid smoke and $\mathrm{NaCl}$ in hot-process smoke-flavored fish. J. Food Prot. 45(10). 935-941

Girard, J.P. 1992. Technology of Meat and Meat Products. Ellis Horwood. New York: 165-201.

Gorbatov, V.M., Krylova, N.N., Volovinskaya, V.P., Lyaskovskaya, Yu.N., K.L. Bazarova, K.L., Khlamova, R.I., and Yakovleva, G.Ya. 1971. Liquid smoke for use in cured meats. Food Techol. 25(1):71-77.

Hasegawa, H. 1987. Laboratory Manual on Analytical Methods and Procedures of Fish and Fish Products. Marine Research Dep. South East Asean Fisheries Development Center. Singapore

Hollenbeck, C.M. 1978. Summaries of additional paper on smoke curing. The Symposium Smoke CuringAdvances in Theory of Food Techology. Dallas. Tex. June 4-7, 1978
James, M.J. 1978. Modern Food Microbiology. Second Edition. van Nostrand Reinhold. Company. New York

Laemli, U.K. 1970. Cleavage of structural protein during assembly of the head of bacteriophage $T_{4}$ Nature. 227 680-685.

Maga, J.A. 1987. Smoke in Food Processing. CRS Press Inc. Boca Raton, Florida. $154 \mathrm{pp}$

Pearson, A.M and Tauber, F.W. 1984. Processed Meats Second Edition. Smoking. Avi. Publishing Company Inc. Westport, Connecticut: $69-85$.

Pitt. J.I and Hocking, A.D. 1985. Fungi and Food Spoilage. Academic Press, Australia.

Ray, B and M. Daeschel. 1993. Food Biopreservatives of Microbial Origin. CRC Press. Boca-Raton: 103-132

Reynold, J.F.F. 1993. Martindale. The Extra Pharmacopodia. 30 ${ }^{\text {th }}$ Edition. The Pharmacentical Press. London.

Ruiter, A. 1979. Color of smoked fish. Food Techol. 33(5): 54-63.

Setiabudi, E., Syarief, F., dan Suryanto, D. 1982. Introdusi prototipe alat pengasar ikan. Laporan Penelitian Teknologi Perikanan. 16: 17-24

Sikorski, Z.E. 1979. Structure and protein of fish and shell fish. Part II dalam Conell. J.J. (Ed). Advances in Fish Science and Technology. Fishery News Book Ltd Farnham. Sirrey.

Syarief, F., Bustaman, S., Suryanto, D., dan Rumahrupute B. 1983. Peningkatan teknik pengolahan cakalang asar di Ambon. Laporan Penelitian Teknologi Perikanan. 21 21-28

Steel, R.D.G and Torrie. J.H. 1981. Principles and Procedures of Statistic a Biometrical Approach, $2^{\text {nd Edi- }}$ tion McGrow. Kogahusha Ltd. Tokyo. 633 pp

Wahyuningtyas, R. 1997. Pemanfaatan Kulit Buah Kakao dan Kopi untuk Pembuatan Asap Cair dan Aplikasinya pada Daging. Skripsi Jurusan Teknologi Pengolahan Hasil Pertanian. Fakultas Teknologi Pertanian, UGM Yogyakarta.

Witigna, F. 1973. Pengaruh Waktu Pengasapan serta Penggunaan Natrium Benzoat terhadap Mutu Bandeng Asap selama Penyimpanan. Fakultas Mekanisasi dan Teknologi Perikanan. IPB. Bogor.

Yulistiani, R. 1997. Kemampuan Penghambatan Asap Cair terhadap Pertumbuhan Bakteri Patogen dan Perusak pada Lidah Sapi. Tesis S-2 Program Studi Ilmu dan Teknologi Pangan. Program Pasca Sarjana UGM, Yogyakarta. 64-81. 
Lampiran 1. Lembar penilaian steak cakalang asar.

Appendix 1. Score sheet for the quality assessment of smoked grilled skipjack.

\begin{tabular}{cl}
\hline Skor (Score) & \multicolumn{1}{c}{ Ketajaman warna (Color intensity) } \\
\hline 3 & Sangat coklat (Dark brown) \\
2 & Coklat (Brown) \\
1 & Coklat/pucat (Brown/pale) \\
\hline \hline
\end{tabular}

\begin{tabular}{cl}
\hline \hline & \\
\hline Skor (Score) & \multicolumn{1}{c}{ Ketajaman bau asap (Smoke colour intensity) } \\
\hline 5 & Amat sangat tajam (Extremely strong) \\
4 & Sangat tajam (Very strong) \\
3 & Tajam (Strong) \\
2 & Kurang tajam (Weak) \\
1 & Tidak berbau asap (No smoke taste) \\
\hline \hline
\end{tabular}

\begin{tabular}{cl}
\hline Skor (Score) & \multicolumn{1}{c}{ Ketajaman rasa asap (Smoke taste intensity) } \\
\hline 5 & Amat sangat tajam (Extremely strong) \\
4 & Sangat tajam (Very strong) \\
3 & Tajam (Strong) \\
2 & Kurang tajam (Weak) \\
1 & Tidak berasa asap (No smoke taste) \\
\hline \hline
\end{tabular}

\begin{tabular}{cl}
\hline Skor (Score) & \multicolumn{1}{c}{ Kekerasan te kstur (Toughness of texture) } \\
\hline 7 & Sangat terlalu keras (Extremely tough) \\
6 & Terlalu keras (Very tough) \\
5 & Agak keras (Slightly tough) \\
4 & Sedang/cukup (Just right) \\
3 & Kurang keras (Soft) \\
2 & Agak lunak (Slightly soft) \\
1 & Terlalu lunak (Very soft) \\
\hline
\end{tabular}

